Reviu Akuntansi dan Bisnis Indonesia, Vol. 1 No. 2, Hlm: 153-170, Desember 2018

Website: http://journal.umy.ac.id/index.php/rab

\title{
Pengaruh Politik Dinasti dan Sistem Pengendalian Internal Terhadap Kinerja Pemerintah Daerah dengan Akuntabilitas Pelaporan Sebagai Variabel Pemediasi : Studi Empiris Pada Pemerintah Daerah Di Indonesia Tahun 2012-2015
}

\author{
Tri Susilo Wahyu Aji; Suryo Pratolo \\ Program Studi Akuntansi Universitas Muhammadiyah Yogyakarta
}

I N F O A R T I K E L

Kata Kunci:

Politik Dinasti, Sistem

Pengendalian Internal,

Kelemahan SPI, Kinerja

Pemda, Akuntabilitas

Pelaporan Keuangan

Pemerintah Daerah.

Jenis Artikel:

Penelitian Empiris

Correspondence:

suryo@umy.ac.id

\begin{abstract}
A B S T R A K
Penelitian ini bertujuan untuk menganalisis pengaruh Politik Dinastidan Sistem Pengendalian Internalterhadap Kinerja pemerintahan dengan Akuntabilitas Pelaporan Keuangansebagai variabel pemediasi. Kinerja pemerintahan dinyatakan dalam Penetapan Peringkat dan Status Kinerja PenyelenggaKementrian Dalam Negeri pada Pemerintah daerah Provinsi, Kab/Kota seluruh Indonesia. Objek penelitian ini adalah seluruh pemerintah provinsi, kabupaten/kota di Indonesiatahun 20122015.Penelitian ini dilakukandengan metode dokumentasi. Data yang digunakan adalah data sekunder, yang bersumber dari Badan Pemeriksa Keuangan Republik Indonesia dan Kementerian Dalam Negeri. Penelitian ini menggunakan analisis data regresi berganda dengan bantuan software komputer untuk statistika SPSS versi 15.Hasil dari penelitian ini menunjukan bahwa praktik Politik Dinasti tidak berpengaruh signifikan terhadap Kinerja pemerintahan.Sistem Pengendalian Internal terbukti berpengaruh signifikan terhadap Kinerja pemerintahan, serta Akuntabilitas tidak terbukti memediasi hubungan antara Politik Dinasti dan SPI terhadap Kinerja pemerintahan.
\end{abstract}

(C) 2019 RAB. Published by Universitas Muhammadiyah Yogyakarta

\section{PENDAHULUAN}

Penyelenggaraan pemerintahan di suatu daerah diperlukan adanya evaluasi. Evaluasi penyelenggaraan Pemerintah Daerah dimaksudkan untuk mengukur kinerja pemerintah daerah. Peraturan Pemerintah (PP) No. 6/2008 menyebutkan bahwa, salah satu evaluasi penyelenggaraan pemerintahan daerah adalah berupa Evaluasi Kinerja Penyelenggaraan Pemerintahan Daerah (EKPPD). Kemudian dilengkapi dengan Peraturan Menteri Dalam Negeri (Permendagri) No. 73 tahun 2009 (Permendagri No.73/2009) tentang Tata Cara Pelaksanaan Evaluasi Kinerja Penyelenggaraan Pemerintahan Daerah.

Kinerja suatu organisasi dinilai baik jika organisasi tersebut mampu melaksanakan tugas-tugas dalam rangka mencapai tujuan yang telah ditetapkan pada standar yang tinggi dengan biaya yang rendah. Tingkat keberhasilan instansi pemerintah harus memperhatikan seluruh aktivitas yang diukur, tidak semata-mata kepada input dari program instansi tetapi lebih ditekankan pada output, 
proses, manfaat, dan dampak dari program instansi tersebut bagi kesejahteraan masyarakat (Sudarsana, 2013).

Beberapa instansi pemerintah telah menggunakan model pengukuran kinerja dengan menggunakan perspektif value for money. Hal ini sesuai dengan hasil penelitian Kurrohman (2012) yang menyebutkan bahwa kinerja keuangan Pemerintah Daerah Kabupaten dan Kota di Jawa Timur sebelum dan sesudah penerapan penganggaran berbasis kinerja menggunakan metode Value for Money menunjukkan adanya perbedaan sebelum dan sesudah penerapan penganggaran berbasis kinerja pada rasio ekonomi dan efisien, tetapi tidak ditemukan perbedaan sebelum dan sesudah penerapan penganggaran berbasis kinerja pada rasio efektif.

Arfan (2014) juga menyebutkan bahwa kinerja Dinas di Daerah Istimewa Yogyakarta tahun 2011-2012 telah menjalankan keseluruhan programnya dengan ekonomis, efisien, dan efektif namun terdapat satu program yang kurang efektif yaitu program Peningkatan Kesejahteraan Petani, karena pada pelaksanaannya capaian kinerja yang dihasilkan kurang maksimal yaitu sebesar 99,29\%. Sementara itu, hasil evaluasi Akuntabilitas Kinerja Instansi Pemerintah Daerah kabupaten dan kota yang disampaikan kementrian pendayagunaan aparatur negara pada 2016 mengalami kenaikan 2,95 poin.

Tabel 1 Skor Kinerja Pemda

\begin{tabular}{lllllll}
\hline Tahun & Sangat Tinggi & Tinggi & Sedang & Rendah & $\begin{array}{l}\text { Jumlah } \\
\text { (Daerah) }\end{array}$ & Data \\
\hline 2011 & $6,3 \%$ & $80,5 \%$ & $13,2 \%$ & - & 365 \\
2012 & $12,3 \%$ & $51,2 \%$ & $36,5 \%$ & - & 373 \\
2013 & $13,6 \%$ & $56,9 \%$ & $24,8 \%$ & $4,7 \%$ & 383 \\
2014 & $27,3 \%$ & $55,2 \%$ & $15,4 \%$ & $2,1 \%$ & 395 & \\
2015 & $37,8 \%$ & $54,9 \%$ & $7 \%$ & $0,3 \%$ & 384 & \\
\hline
\end{tabular}

Sumber: Kemendagri

Tabel diatas merupakan hasil penilaian kinerja yang dilakukan oleh Kementrian Dalam Negeri (Kemendagri RI) atas Laporan Penyelenggaraan Pemerintah Daerah (LPPD) seluruh Indonesia yang telah diterbitkan. Dengan adanya pengukuran tersebut dapat menciptakan iklim organisasi untuk terus meningkatkan kinerjanya dalam mencapai tujuan organisasi.

Konsep pengukuran kinerja menjadi sebuah instrumen yang penting untuk mengetahui sejauh mana prestasi daerah otonom dalam menjalankan pemerintahannya secara objektif (Pratolo dan Jatmiko, 2017). Otonomi daerah adalah hak, wewenang, dan kewajiban daerah otonom untuk mengatur dan mengurus sendiri urusan pemerintahan dan kepentingan masyarakat setempat sesuai dengan peraturan perundang-undangan (Sijabat, 2016). Kemandirian inilah yang menguatkan perlu adanya pengukuran kinerja. Karena banyaknya urusan yang harus ter-kover oleh Pemerintah Daerah, menjadikan sering adanya bagian-bagian yang terlupakan untuk diperhatikan dalam mengurus pemerintahan tersebut. Pengukuran kinerja yang berkelanjutan dapat memberikan umpan balik bagi proses perbaikan secara terus-menerus untuk mencapai keberhasilan organisasi (Pratolo \& Jatmiko, 2017).

Pelaksanaan otonomi daerah memunculkan risiko terjadinya kontrol penuh oleh elit lokal. Pada banyak daerah di Indonesia, para elit lokal membangun politik dinasti dengan memanfaatkan mekanisme sah demokrasi yang terdesentralisasi, yakni pemilihan umum kepala daerah (Halim, 2014). Masalah lainnya yang muncul adalah meningkatnya kecenderungan eksekutif yang lebih kuat dari legislatif (Nuritomo dan Rossieta, 2014). Harapan untuk meningkatnya kesejahteraan rakyat banyak terhambat oleh adanya pemanfaatan yang salah dari beredarnya kekuasaan di daerah.

Politik kekerabatan atau yang lebih dikenal sebagai Politik Dinasti adalah mereka yang mewarisi jabatan publik yang sama dari anggota keluarga mereka yang memegangnya sebelum mereka (Asako dkk, 2010). Variabel independen selanjutnya adalah Sistem Pengendalian Internal yang diharapkan mampu meredam dampak buruk yang ditimbulkan dari adanya praktik politik dinasti di suatu pemerintah daerah. Dengan adanya SPI yang baik dapat meningkatkan kinerja pemerintah yang terdapat praktik politik dinasti. 
Penelitian ini memodifikasi model penelitian sebelumnya dengan mengaplikasikan akuntabilitas keuangan pemerintah daerah sebagai variabel mediasi (intervening), dalam penelitian Nuritomo \& Rossieta (2014), menggunakan akuntabilitas sebagai variabel moderasi. Mengidentifikasi hubungan antar variabel yang tepat membutuhkan pemahaman mengenai kapan pilihan-pilihan model kausal tersebut terjadi dan tidak terjadi konflik (Luft \& Shield, 2003).

Penelitian ini merupakan pengembangan dari penelitian-penelitian tentang kinerja organisasi sektor publik, terutama pada pemerintah daerah. penelitian ini mereplikasi, memodifikasi dan memperluas penelitian Nuritomo dan Rossieta (2014), Irmawati (2015) dan Kautsar (2015) yang terdapat variabel politik dinasti, akuntabilitas dan kinerja didalamnya namun dengan instrumen yang dikembangkan lebih luas.

\section{TINJAUAN LITERATUR DAN PERUMUSAN HIPOTESIS}

\section{Teori Organisasi}

Organisasi adalah sistem yang saling berpengaruh antar orang dalam kelompok yang bekerjasama untuk mencapai tujuan tertentu. Pratolo (2015) menyebutkan terdapat 4 karakteristik yang dimiliki sebuah organisasi. (1) Terdiri dari dua orang atau lebih yang saling bekerjasama dan mempunyai suatu jalur komunikasi tertentu. (2) Adanya jabatan dan pembagian tugas antar individu di dalamnya. (3) Memiliki Wewenang, Koordinasi dan Pengawasan sebagai wujud kontrol manajemen. Dan (4) Adanya tujuan jangka panjang dan jangka pendek yang ingin dicapai.

\section{Teori Stewardship}

Teori stewardship atau pengabdian beranggapan bahwa manusia pada hakikatnya mampu bertindak dengan penuh tanggung jawab, dapat dipercaya, berintegritas tinggi dan memiliki kejujuran. Teori stewardship memandang agent sebagai pihak yang mampu melaksanakan tindakan yang sebaik-baiknya ditujukan untuk memenuhi kebutuhan principal. Konsep pada teori ini didasarkan pada asas kepercayaan pada pihak yang diberikan wewenang, dimana agent dalam suatu organisasi atau pemerintah dicerminkan sebagai good steward yang melaksanakan tugas yang diberikan oleh atasannya atau principal secara penuh tanggung jawab (Irmawati, 2015).

\section{Good Governance dan Akuntabilitas}

Akuntabilitas adalah tentang pemberian suatu laporan tentang apa, bagaimana dan mengapa sumber daya dialokasikan untuk tujuan tertentu, bagaimana kekuasaan dijalankan dan hubungan antara kekuasaan yang dijalankan dengan hasil yang diharapkan dan dicapai (Haning, 2005). Jadi pengertian akuntabilitas tidak hanya sebatas kewajiban terhadap pelaporan hasil kerja, namun mencakup juga pencapaian tujuan dari apa yang dilakukan. Dari perspektif sistem akuntabilitas, terdapat beberapa karakteristik pokok akuntabilitas yaitu, berfokus pada hasil, menggunakan beberapa indikator yang telah dipilih untuk mengukur kinerja, menghasilkan informasi yang berguna bagi pengambilan keputusan atas suatu program atau kebijakan, menghasilkan data secara konsisten dari waktu ke waktu, serta melaporkan hasil dan mempublikasikannya secara teratur (Sadjiarto, 2000).

\section{Pengaruh Politik Dinasti dan Akuntabilitas Pelaporan}

Fenomena politik dinasti merupakan gejala yang dapat menimbulkan proses pengambilan keputusan di daerah menjadi tidak efisien dan efektif. Sumberdaya yang cakap cenderung tidak mampu mendapatkan tempat untuk mengelola keuangan daerah yang baik (Adzani \& Martani, 2014). 
Ketika suatu pemimpin pemerintahan berasal dari dinasti politik, hal itu akan memicu penempatan-penempatan individu yang memiliki hubungan istimewa pada posisi-posisi strategis dalam pemerintahan. Pada seharusnya, penempatan tersebut harus didasarkan pada kualifikasi yang tepat untuk menjalankan tugas-tugas pelayanan didalamnya. Adanya sikap-sikap tidak independen dari hubungan istimewa tersebut dapat menurunkan pengawasan pada pelaksanaan tugas-tugas dan pelaporan penyelenggaraan pemerintahan. Maka diajukan hipotesis:

\section{$\boldsymbol{H}_{\boldsymbol{i}} \quad$ : Politik Dinasti Berpengaruh Negatif Terhadap Akuntabilitas Pelaporan Di Pemerintah Daerah.}

\section{Pengaruh Sistem Pengendalian Internal (SPI) dan Akuntabilitas Pelaporan}

Sistem Pengendalian Internal yang di proksikan oleh temuan audit adalah hasil audit yang menjelaskan semua hal yang berkaitan dengan kelemahan dalam pengendalian intern atas pelaporan keuangan yang dianggap sebagai kondisi yang dapat dilaporkan (Munawar dkk, 2016). Ketika suatu organisasi pemerintah daerah mempunyai temuan pelanggaran-pelanggaran yang tinggi terhadap sistem pengendalian internal yang dimilikinya, hal tersebut dapat semakin memperburuk capaian opini atas pelaporan yang dipakai sebagai proksi pengukur dari akuntabilitas pelaporan di pemerintah daerah. Ketika suatu pemerintah dapat menekan angka pelanggaran terhadap SPI maka tingkat opini yang diperoleh akan semakin tinggi dan mengartikan suatu bentuk akuntabilitas pelaporan yang baik. Maka diajukan hipotesis:

\section{$\mathrm{H}_{2} \quad$ : Sistem Pengendalian Internal Berpengaruh Positif Terhadap Akuntabilitas Pelaporan Di Pemerintah Daerah.}

\section{Pengaruh Politik Dinasti Dan Kinerja Pemerintahan}

Politik dinasti membawa lebih besar transfer dana kepada daerah dinasti dibandingkan nondinasti dan membuat kinerja pembangunan lebih rendah meskipun alokasi dana transfer dari pusat lebih besar (Asako dkk 2012). Selain itu, menguatnya dinasti politik berdampak pula pada besarnya potensi korupsi yang dilakukan para anggota keluarga dinasti yang berkuasa (Hasibuan, 2013).

Politik dinasti dapat tercipta dari sebuah keluarga yang telah dirancang untuk terjadinya perpindahan kekuasaan di suatu saat kemudian. Dengan berjalannya praktik politis ini, kepada daerah terpilih yang kurang kompeten hanya akan menjalankan pemerintahan berdasar dari kepala daerah sebelumnya yang masih memiliki hubungan istimewa terhadap eksekutif terpilih tersebut. Kinerja pemerintahan akan semakin menurun karena kurangnya kompetensi yang dimiliki. Maka diajukan hipotesis:

\section{$H_{s} \quad$ : Politik Dinasti Berpengaruh Negatif Terhadap Kinerja Pemerintah Daerah.}

\section{Pengaruh Akuntabilitas dan Kinerja Pemerintah}

Akuntabilitas kinerja merupakan perwujudan kewajiban suatu penyelenggara pemerintahan untuk mempertanggungjawabkan keberhasilan maupun kegagalan dalam mencapai tujuan dan sasaran periodik yang diukur dengan seperangkat indikator kinerja (Rohman, 2009). Apabila pertanggungjawaban pejabat publik terhadap masyarakat diterapkan dengan baik oleh pemerintah kepada masyarakat, maka akan menimbulkan suatu kepercayaan yang tinggi dari masyarakat kepada pemerintah sehingga kinerja pemerintah daerah akan menjadi lebih baik. Maka diajukan hipotesis: 
$\boldsymbol{H}_{4}$ : Akuntabilitas Berpengaruh Positif Terhadap Kinerja Pemerintah Daerah.

\section{Pengaruh Sistem Pengendalian Internal dan Kinerja Pemerintah}

Peraturan BPK Nomor 1 Tahun 2007 yang menyatakan bahwa laporan atas pengendalian intern harus mengungkapkan kelemahan dalam pengendalian intern atas pelaporan keuangan yang dianggap sebagai kondisi yang dapat dilaporkan. Pemahaman tentang temuan audit atas SPI adalah hasil audit yang menjelaskan semua hal yang berkaitan dengan kelemahan dalam pengendalian intern atas pelaporan keuangan yang dianggap sebagai kondisi yang dapat dilaporkan.

Jika penerapan SPI berjalan dengan baik maka kinerja pemerintah dalam pengelolaan anggaran daerah akan akuntabel dan transparan, begitu juga sebaliknya jika penerapan SPI tidak berjalan dengan optimal maka akan memungkinkan terjadi penyalahgunaan kekuasaan untuk melakukan penyimpangan. Maka diajukan hipotesis:

$\boldsymbol{H}_{s} \quad$ : Sistem Pengendalian Internal Berpengaruh Positif Terhadap Kinerja Pemerintah Daerah.

\section{Pengaruh Politik Dinasti, Akuntabilitas Pelaporan dan Kinerja Pemerintah}

Politik dinasti dianggap tidak berpengaruh terhadap kinerja pemda (Nuritomo \& Rossieta, 2014), ketidakadanya pengaruh dinasti politik terhadap kinerja keuangan Pemda disebabkan karena masih besarnya dana transfer dari pemerintah pusat yang mengakibatkan, kemandirian daerah dalam menghasilkan pendapatan asli daerah masih rendah (Kautsar, 2015). Namun, dengan adanya sistem pengelolaan keuangan daerah yang mencakup sistem pelaporan, akan menciptakan pengelolaan keuangan yang transparan dan akuntabel, dimana sistem pelaporan yang baik akan mencantumkan penjelasan mengenai penyebab terjadinya penyimpangan, tindakan yang diambil untuk mengoreksi penyimpangan yang tidak menguntungkan dan waktu yang dibutuhkan agar tindakan koreksi lebih efektif demi meningkatkan akuntabilitas kinerja (Hidayatullah, 2015). Maka diajukan hipotesis:

\section{$\boldsymbol{H}_{6} \quad$ : Akuntabilitas Pelaporan Memediasi Pengaruh Positif Politik Dinasti Terhadap Kinerja Pemerintah Daerah.}

\section{Pengaruh Sistem Pengendalian Internal, Akuntabilitas Pelaporan dan Kinerja Pemerintah}

Pengendalian internal didesain untuk memberikan keyakinan memadai dalam pencapaian tujuan keandalan pelaporan keuangan, efektivitas dan efisiensi operasi, serta kepatuhan terhadap hukum dan peraturan yang berlaku (Arens dkk, 2008). Sarita (2012) menyebutkan bahwa sistem pengendalian intern yang efektif akan berpengaruh terhadap kinerja dalam pencapaian efektivitas, efisiensi, ketaatan terhadap peraturan perundang- undangan yang berlaku, dan keandalan penyajian laporan keuangan pemerintah. Maka diajukan hipotesis:

\section{$H_{7} \quad$ : Akuntabilitas Pelaporan Memediasi Pengaruh Positif Sistem Pengendalian Internal Terhadap Kinerja Pemerintah Daerah.}

\section{METODE PENELITIAN}

Objek penelitian ini dilakukan pada Kabupaten dan Kota diseluruh Indonesia pada tahun 2012-2015. Jenis data pada penelitian ini adalah data sekunder. Data diperoleh dari data kinerja pemerintah daerah yang diterbitkan oleh Kemendagri RI dan data opini audit pemda oleh BPK 
RI. Teknik pengambilan sampel pada penelitian ini menggunakan metode purposive sampling, dengan kriteria:

a. Pemerintah daerah yang terindikasi politik dinasti. Definisi politik dinasti yang digunakan pada penelitian ini adalah politik dinasti dalam lingkup pemimpin eksekutif pemerintah daerah atau kepala daerah (gubernur/bupati/walikota dan wakil gubernur/wakil bupati/wakil walikota)

b. Jenis pemerintah daerah Prifinsi dan Kabupaten/Kota

c. Pemerintah daerah yang memiliki data sesuai dengan variabel-variabel yang dibutukan dalam penelitian.

Metode Pengumpulan data yang digunakan dalam penelitian ini adalah dengan cara dokumentasi dan studi pustaka. Dokumentasi adalah suatu cara pengumpulan data dengan mengumpulkan dan mempelajari dokumen dari instansi yang bersangkutan.

\title{
Definisi Operasional Variabel Penelitian
}

\section{Kinerja pemerintah daerah}

Ukuran kinerja penyelenggaran pemerintah daerah dalam penelitian ini menggunkan skor Evaluasi Kinerja Penyelenggaran Pemerintah Daerah (EKPPD) atas Laporan Penyelenggaraan Pemerintahh Daerah (LPPD) yang diterbitkan oleh kementrian dalam negeri RI. Dalam rentang nilai 0-4, dengan kategori sebagai berikut:

a) Skor $0-1=$ Rendah

b) Skor $1-2=$ Sedang

c) Skor $2-3=$ Tinggi

d) Skor $3-4=$ Sangat Tinggi.

\section{Politik Dinasti}

Variable ini diukur menggunakan variabel dummy sepeti dalam penelitian Nuritomo \& Rosieta (2014). Skor "1" untuk daerah yang terindikasi menjalankan politik dinasti pada kepala daerah serta "0" untuk daerah yang tidak terindikasi menjalankan praktik politik dinasti.

\section{Sistem Pengendalian Internal}

Variabel ini di ukur menggunakan nilai temuan audit atas Sistem Pengendalian Internal yang dihitung menggunakan rumus skala rasio dari jumlah penegakan SPI. Dihitung menggunakan jumlah pelanggaran atas SPI terhadap jumlah seluruh SPI yang diperiksa dalam Laporan Hasil Pemeriksaan BPK RI.

$$
S P I=1-\frac{\text { Jumlah pelanggaran SPI }}{\text { Total SPI yang diperiksa }}
$$

\begin{abstract}
Akuntabilitas
Variabel ini diukur menggunakan proksi opini audit yang dikeluarkan oleh BPK, diukur menggunakan skala ordinal dari paling rendah sampai tinggi yaitu 1 = Tidak menyatakan pendapat (TMP) , 2 = Tidak Wajar (TW) , $3=$ Wajar Dengan Pengecualian (WDP) , $4=$ Wajar Tanpa Pengecualian Dengan Paragraf Penjelas ( WTP-DPP) , $5=$ Wajar Tanpa Pengecualian (WTP) (Irmawati, 2015).
\end{abstract}




\section{Uji Kualitas Data}

\section{Uji Statistik Deskriptif}

Uji statistik deskriptif memiliki tujuan yaitu untuk menggambarkan masing-masing variabel yang digunakan dalam penelitian. Uji ini digunakan untuk mendeskripsikan suatu data yang dilihat dari nilai minimum, nilai maksimum, nilai rata-rata, dan standar deviasi (Ghozali, 2011).

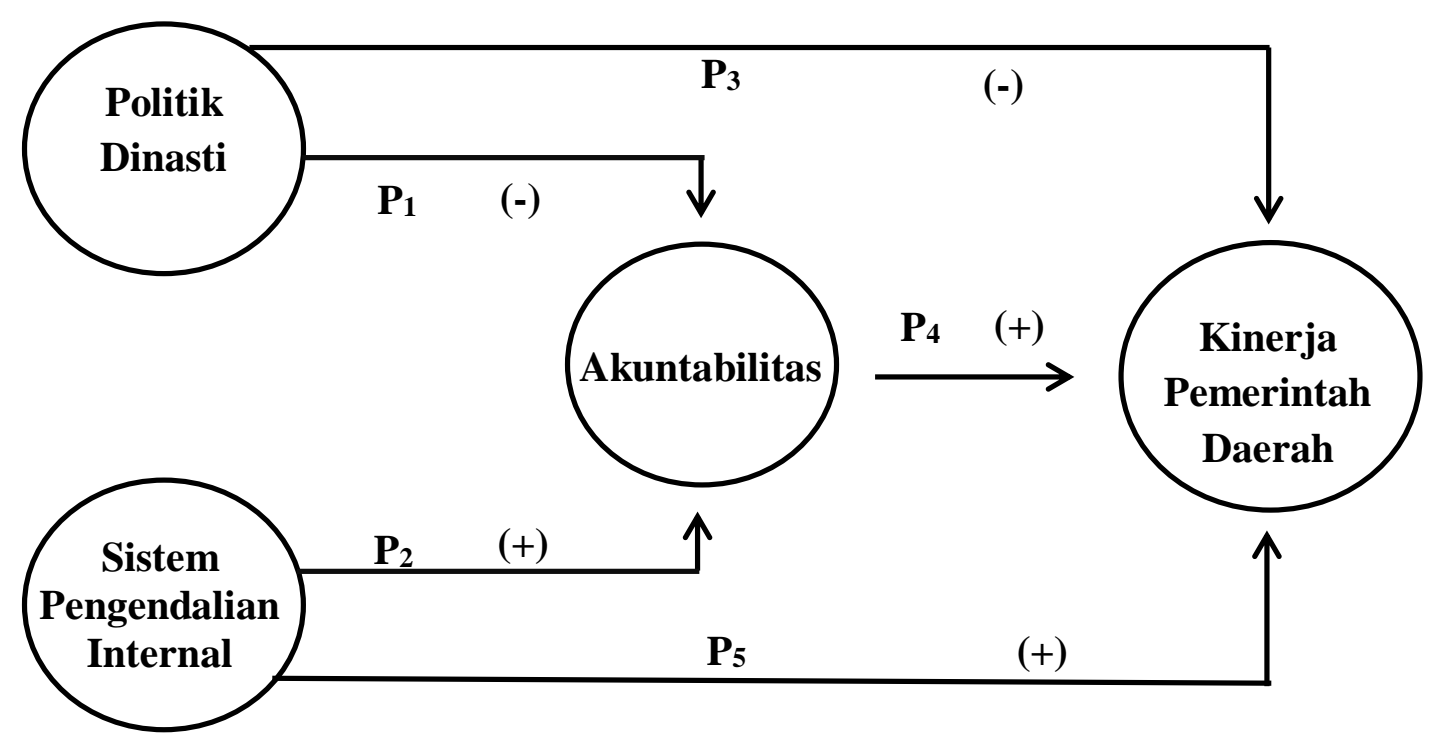

Gambar 1 Model Penelitian Analisis Jalur

\section{Uji Asumsi Klasik}

\section{Uji Normalitas}

Uji normalitas dilakukan menggunakan uji Kolmogorov Smirnov. Uji normalitas digunakan untuk melihat apakah residual data berdistribusi normal atau tidak. Residual data dinyatakan berdistribusi normal apabila nilai asymp sig (2-tailed) >0,05 (alpha).

\section{Uji Autokorelasi}

Pengambilan keputusan ada atau tidaknya autokorelasi dapat dilihat dari ketentuan berikut (Santoso, 2012):

a) Terjadi autokorelasi positif jika D-W terletak di bawah -2

b) Tidak terjadi autokorelasi jika D-W diantara -2 sampai +2

c) Terjadi autokorelasi negatif jika D-W terletak diatas +2

\section{Uji Multikolinearitas}

Uji multikolinearitas digunakan untuk melihat hubungan independen yang satu dengan variabel independen yang lain. Data dinyatakan tidak terkena gejala multikolinearitas apabila nilai VIF < 10 atau nilai tolerance $>0,1$.

\section{Uji Heteroskedastisitas}

Uji heteroskedastisitas digunakan untuk melihat apakah data bersifat heterogen atau homogen. Data yang baik memiliki sifat homogen, ketika data heterogen maka data terkena heteroskedastisitas. 
Pengujian heteroskedastisitas berupa Uji Glejser. Syarat agar data tidak terkena heteroskedastisitas adalah jika sig >0,05 (alpha).

\section{Uiji hipotesis}

\section{Analisis jalur (path analysis)}

Untuk menguji hipotesis $\mathrm{H}_{1}, \mathrm{H}_{2}, \mathrm{H}_{3}, \mathrm{H}_{4}, \mathrm{H}_{5}, \mathrm{H}_{6}$ dan $\mathrm{H}_{7}$ alat uji yang digunakan adalah tekhnik analisis jalur (path analysis) dengan mengunakan bantuan program Statistical Package for The Social Sciences (SPSS) versi 15. Dapat dilihat pada Gambar 1, koefisien jalur (path) adalah standardize koefisien regresi, koefisien jalur dari model penelitian yaitu: P1, P2, P3, P4, dan P5 dihitung dengan membuat dua persamaan regresi yang menunjukkan hubungan yg dihipotesiskan.

\section{Substruktur 1 \\ Pengujian hipotesis $\mathbf{H}_{1}$ dan $\mathbf{H}_{2}$}

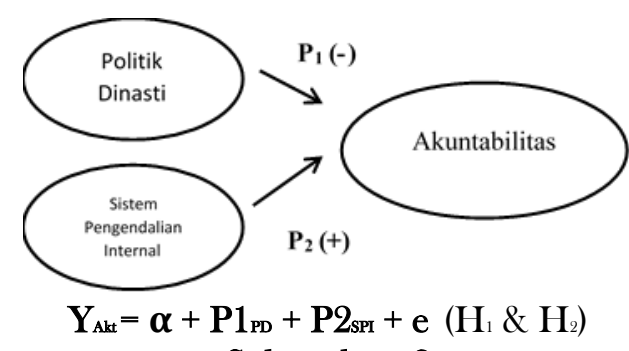

Substruktur 2

Pengujian hipotesis $\mathbf{H}_{3}, \mathbf{H}_{4}$ dan $\mathbf{H}_{5}$

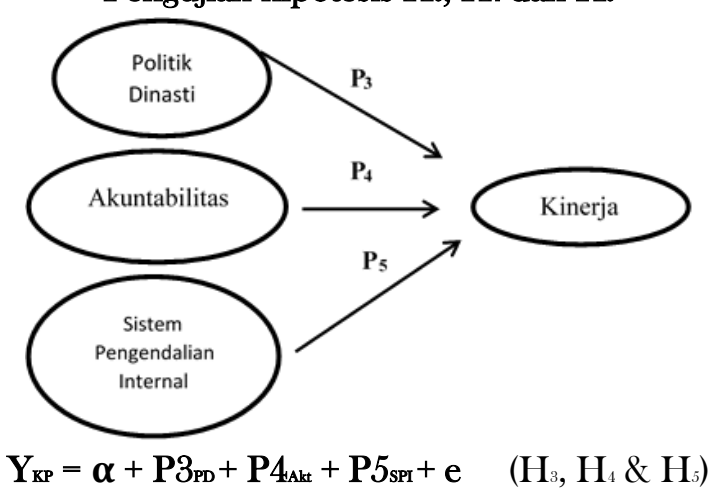

\section{Keterangan :}

$Y_{\text {akt }}=$ Akuntabilitas Pelaporan Daerah (variabel pemediasi)

$\mathrm{Y}_{\mathrm{KP}}=$ Kinerja Pemerintah (variabel terikat)

$\alpha=$ Konstanta

P1 $=$ Koefisien regresi dari PD (variabel bebas)

PD $=$ Politik Dinasti

P2 = Koefisien regresi dari SPI (variabel bebas)

SPI $=$ Sistem Pengendalian Internal

Akt $=$ Akuntabilitas

P3 = Koefisien regresi dari PD (variabel bebas)

P4 $=$ Koefisien regresi dari SPI (variabel pemediasi)

P5 $=$ Koefisien regresi dari Akt (variabel bebas)

Untuk mengetahui pengaruh langsung atau tidak langsung politik dinasti dan sistem pengendalian internal terhadap kinerja pemerintah, maka dilakukan interpretasi terhadap koefisien jalur (path). 


\section{Pengujian hipotesis $\mathbf{H}_{6}$}

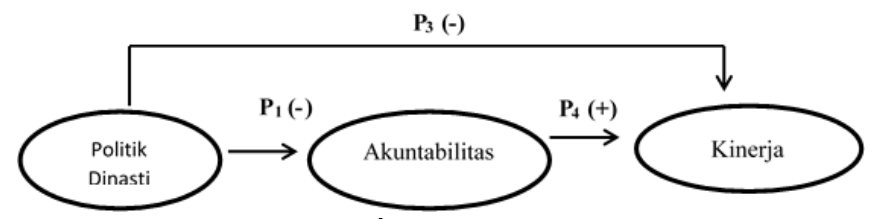

$\left(\mathrm{P} 1{ }^{*} \mathrm{P} 4\right) \geq \mathrm{P3}^{2}$

Pengaruh Akuntabilitas pelaporan yang memediasi Politik Dinasti ke Kinerja Pemerintah secara tidak langsung terjadi apabila perbandingan pengaruh tidak langsung yaitu koefisien path dari Politik Dinasti ke Akuntabilitas yaitu P1 dikalikan dengan koefisien path dari Akuntabilitas ke Kinerja Pemerintah yaitu P5 lebih besar sama dengan adalah pengaruh langsung Politik Dinasti ke Kinerja Pemerintah (koefisien path atau regresi P32).

\section{Pengujian hipotesis $\mathbf{H}_{7}$}

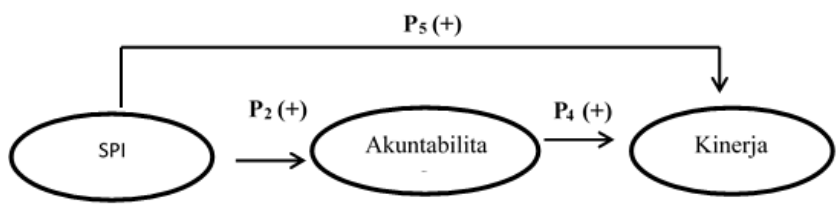

$\left(\mathrm{P} 2{ }^{*} \mathrm{P} 4\right) \geq \mathrm{P} 5{ }^{2}$ .$\left(\mathrm{H}_{7}\right)$

Pengaruh Akuntabilitas pelaporan yang memediasi SPI ke Kinerja Pemerintah secara tidak langsung terjadi apabila perbandingan pengaruh tidak langsung yaitu koefisien path dari SPI ke akuntabilitas yaitu P2 dikalikan dengan koefisien path dari Akuntabilitas ke Kinerja Pemerintah yaitu P5 lebih besar sama dengan adalah pengaruh langsung SPI ke Kinerja Pemerintah (koefisien path atau regresi $\mathrm{P} 42$ ).

\section{HASIL DAN PEMBAHASAN}

Tabel 2 Ringkasan Pengambilan Sampel

\begin{tabular}{cc}
\hline Kriteria Sampel & Jumlah \\
\hline Kabupaten/Kota yang terindikasi menjalankan praktik Politik Dinasti TA 2012/2015 & 108 \\
Kabupaten/Kota yang tidak dimuat skor Kinerja oleh Kemendagri & $(3)$ \\
Kabupaten/Kota yang yang tidak memiliki skor pelanggaran SPI dalam LHP BPK RI & $(78)$ \\
Jumlah Sampel terpilih & 27 \\
Kabupaten/Kota yang menjadi sampel pembanding (matched Sampling) & 27 \\
Jumlah Data sampel yang diolah & 54 \\
\hline
\end{tabular}

Berdasarkan metode purposive sampling yang telah ditetapkan, maka diperoleh jumlah Kabupaten/Kota yang terindikasi menjalankan praktik politik dinasti TA 2012-2015 berjumlah 27 daerah, sehingga daerah yang terpilih menjadi daerah pembanding (matched sampling) juga sejumlah 27 daerah. 
Tabel 3 Hasil Uji Statistik Deskriptif

\begin{tabular}{|c|c|c|c|c|c|}
\hline & & $\begin{array}{l}\text { POLITIK } \\
\text { DINASTI }\end{array}$ & $\begin{array}{l}\text { PENGENDALIAN } \\
\text { INTERNAL }\end{array}$ & AKUNTABILITAS & KINERJA \\
\hline $\begin{array}{l}\mathrm{N} \\
\text { Valid }\end{array}$ & & 54 & 54 & 54 & 54 \\
\hline Missing & & 0 & 0 & ) & ) \\
\hline Mean & & & .333333 & 3.814815 & 2.725598 \\
\hline Median & & 1.000000 & .333333 & 3.000000 & 2.731200 \\
\hline Std. Deviatio & & .5015699 & .3237620 & 1.1001556 & .3723196 \\
\hline Minimum & & .0000 & .0000 & 1.0000 & 1.6286 \\
\hline Maximum & & 1.0000 & 1.0000 & 5.0000 & 3.2908 \\
\hline Percentiles & 25 & .000000 & .000000 & 3.000000 & 2.526100 \\
\hline & 50 & 1.000000 & .333333 & 3.000000 & 2.731200 \\
\hline & 75 & 1.000000 & .416667 & 5.000000 & 3.034775 \\
\hline
\end{tabular}

Sumber: Output data analisis SPSS 15.0

1. Variable Politik Dinasti yang di proksikan dengan status kepemimpinan dengan menggunakan variable dummy memiliki nilai minimum 0 untuk daerah yang tidak terindikasi politik dinasti dan nilai maksimum 1 untuk daerah yang terindikasi menjalankan praktik politik dinasti.

2. Variabel Sistem Pengendalian Internal menggunakan skor penegakan SPI di lingkungan pemerintah daerah sebagai proksi dengan rasio penegakan sebagai metode perhitungan menunjukkan nilai minimum sebesar 0,0000 dan nilai maksimum sebesar 1,0000. Hal tersebut menunjukkan penegakan SPI di lingkungan pemerintah daerah yang dijadikan sampel paling sedikit sebesar 0,0000 dan penegakan paling tinggi memiliki nilai 1,0000. Nilai rata-rata (mean) sebesar 0,3333 berada di dekat angka median sebesar 0,3333 atau percentile 50 dan dibawah percentile 75, hal itu menunjukkan tingkat penegakan SPI yang cukup rendah di lingkungan pemerintah daerah. Selain itu juga diketahui terdapat penyimpangan data yang kecil ditunjukkan dengan nilai standard deviation 0, 3237620 lebih kecil dari nilai rata-rata (mean).

3. Variabel Akuntabilitas yang diproksikan dengan opini audit laporan keuangan menggunakan skala ordinal sebagai perhitungan dalam mengukur tingkat Akuntabilitas Pemerintah Daerah memiliki nilai minimum sebesar 1 dan nilai maksimum sebesar 5 karena menggunakan skala ordinal 1-5. Memiliki nilai rata-rata (mean) sebesar 3,8148 lebih besar dari nilai median 3,00 atau percentile 50 dan dibawah percentile 75 , hal ini menunjukkan tingkat perolehan opini audit yang didominasi memperoleh WDP (Wajar Dengan Pengecualian), sehingga semkin tinggi tingkat perolehan opini audit semakin tinggi tingkat akuntabilitas pelaporan di pemerinntahan daerah. Dapat diketahui juga penyimpangan data yang kecil karena nilai standard deviation sebesar 1,1001 lebih kecil dari nilai rata-rata (mean).

4. Variable Kinerja yang diproksikan skor Kinerja penyelenggaraan pemerintahan daerah yang diterbitkan Kemendagri memiliki nilai minimum sebesar 1,6286 dengan nilai maksimum sebesar 3,2908 hal ini menunjukkan data skor kinerja yang dijadikan sampel penelitian sebesar 1,6286 - 3,2908. Nilai rata-rata (mean) sebesar 2,725598 sama besar dengan nilai median 2,731200 atau nilai percentile 50 dan dibawah percentile 75 , hal tersebut menunjukkan perolehan skor kinerja dari pemerintah daerah yang dijadikan sampel cukup tinggi. Dapat diketahui juga penyimpangan yang kecil diutnjukkan dengan nilai standard deviation sebesar 0,3723196 lebih kecil dari rata-rata (mean).

\section{Uji Kualitas Data}

\section{Uji Asumsi Klasik}

\section{Uji Normalitas}




\section{Substruktur 1}

Tabel 4.1 Uji Normalitas Data

One-Sample Kolmogorov-Smirnov Test

\begin{tabular}{lll}
\hline & & Unstandardized Residual \\
\hline $\mathrm{N}$ & & 54 \\
Normal Parameters(a,b) & Mean & .0000000 \\
& Std. Deviation & .99341326 \\
Most Extreme Differences & Absolute & .116 \\
& Positive & .091 \\
& Negative & -.116 \\
Kolmogorov-Smirnov Z & & .855 \\
Asymp. Sig. (2-tailed) & & .458 \\
\hline
\end{tabular}

Sumber: Output SPSS, 2017

Berdasarkan Tabel 4.1 didapatkan hasil bahwa nilai Asymp. Sig (2-tailed) sebesar 0,458 > $\alpha(0,05)$ yang berarti bahwa data residual terdistribusi normal dan model regresi layak digunakan dalam penelitian ini.

\section{Substruktur 2}

Tabel 4.2 Uji Normalitas Data

One-Sample Kolmogorov-Smirnov Test

\begin{tabular}{ccc}
\hline & & Unstandardized Residual \\
\hline N & & 54 \\
& Mean & .0000000 \\
Most Extreme Differences & Std. & .33788148 \\
& Deviation & .077 \\
& Absolute & .064 \\
Kolmogorov-Smirnov Z & Positive & -.077 \\
Asymp. Sig. (2-tailed) & Negative & .569 \\
\hline
\end{tabular}

Sumber: Output SPSS, 2017

Berdasarkan Tabel 4.4 didapatkan hasil bahwa nilai Asymp. Sig (2-tailed) sebesar 0,902 > $\alpha(0,05)$ yang berarti bahwa data residual terdistribusi normal dan model regresi layak digunakan dalam penelitian ini.

\section{Uji Multikolinieritas}

\section{Substruktur 1}

Tabel 5.1 Uji Multikolinearitas

Coefficients ${ }^{2}$

\begin{tabular}{lll} 
& \multicolumn{2}{c}{ Coefficients $^{a}$} \\
\hline Model & $\begin{array}{l}\text { Collinearity Statistics } \\
\text { Tolerance }\end{array}$ & VIF \\
\hline 1 (Constant) & & \\
POLITIK DINASTI & .986 & 1.014 \\
PENGENDALIAN INTERNAL & .986 & 1.014 \\
\hline
\end{tabular}

Dependent Variable: AKUNTABILITAS

Sumber: Output SPSS, 2017

Tabel 5.1. menunjukkan nilai tolerance untuk semua variabel independen dalam penelitian ini lebih besar dari 0,1 dan nilai variance inflation factor (VIF) untuk semua variabel independen kurang dari 10. Maka dapat disimpulkan bahwa model regresi dalam penelitian ini tidak terjadi masalah multikolinieritas. 


\section{Substruktur 2}

Tabel 5.2 Uji Multikolinearitas Coefficients $^{2}$

\begin{tabular}{|c|c|c|}
\hline \multirow[b]{2}{*}{ Model } & \multicolumn{2}{|l|}{ Coefficients $^{a}$} \\
\hline & $\begin{array}{l}\text { Collinearity Statistics } \\
\text { Tolerance }\end{array}$ & VIF \\
\hline 1(Constant) & & \\
\hline POLITIK DINASTI & .874 & 1.144 \\
\hline PENGENDALIAN INTERNAL & .878 & 1.140 \\
\hline AKUNTABILITAS & .815 & 1.226 \\
\hline
\end{tabular}

Dependent Variable: KINERJA

Sumber: Output SPSS, 2017

Tabel 5.2. menunjukkan nilai tolerance untuk semua variabel independen dalam penelitian ini lebih besar dari 0,1 dan nilai variance inflation factor (VIF) untuk semua variable independen kurang dari 10. Maka dapat disimpulkan bahwa model regresi dalam penelitian ini tidak terjadi masalah multikolinieritas.

\section{Uji Heteroskedastisitas}

\section{Substruktur 1}

Tabel 6.1 Uji Heteroskedastisitas Coefficients $^{\mathrm{a}}$

\begin{tabular}{lll}
\hline \multicolumn{1}{c}{ Model } & $\mathrm{t}$ & Sig. \\
\hline 1(Constant) & 6.366 & .000 \\
POLITIK DINASTI & .202 & .841 \\
PENGENDALIAN INTERNAL & -.743 & .461 \\
\hline
\end{tabular}

Dependent Variable: ABS_RES

Sumber: Output SPSS, 2017

Tabel 6.1. menunjukkan bahwa semua variabel independen memiliki nilai signifikansi lebih besar dari 0,05. Dengan demikian, model regresi dalam penelitian ini bebas dari masalah heteroskedastisitas.

Substruktur 2

Tabel 6.2 Uji Heteroskedastisitas Coefficients $^{2}$

\begin{tabular}{lll}
\hline \multicolumn{1}{c}{ Model } & $\mathrm{t}$ & Sig. \\
\hline 1(Constant) & & .001 \\
POLITIK DINAS & 3.629 & .749 \\
PENGENDALIAN INTERNAL & .321 & .237 \\
AKUNTABILITAS & -1.197 & .279 \\
\hline
\end{tabular}

Dependent Variable: ABS_RES

Sumber: Output SPSS, 2017

Tabel 6.2. menunjukkan bahwa semua variable independen memiliki nilai signifikansi lebih besar dari 0,05. Dengan demikian, model regresi dalam penelitian ini bebas dari masalah heteroskedastisitas.

\section{Uji Autokorelasi}




\section{Substruktur 1}

Tabel 7.1 Uji Autokorelasi

Model Summary

\begin{tabular}{llll}
\hline Model & Adjusted R Square & Std. Error of the Estimate & Durbin-Watson \\
\hline 1 & .153 & 1.0127046 & 1.510 \\
\hline Predictors: PENGENDALIAN INTERNAL, POLITIK DINASTI &
\end{tabular}

Dependent Variable: AKUNTABILITAS

Sumber: Output SPSS 2017

Tabel 7.1. menunjukkan nilai Durbin Watson sebesar 1.51 yang terletak diantara -2 sampai +2 , sehingga dapat disimpulkan bahwa data regresi dalam penelitian ini tidak terjadi masalah autokorelasi.

\section{Substruktur 2}

Tabel 7.2 Uji Autokorelasi

Model Summary

\begin{tabular}{llll}
\hline Model & Adjusted R Square & Std. Error of the Estimate & Durbin-Watson \\
\hline 1 & .127 & .3478703 & 1.840 \\
\hline
\end{tabular}

Predictors: AKUNTABILITAS, PENGENDALIAN INTERNAL, POLITIK DINASTI

Dependent Variable: KINERJA

Sumber: Output SPSS 2017

Tabel 7.2. menunjukkan nilai Durbin Watson sebesar 1,840 yang terletak diantara -2 sampai +2, sehingga dapat disimpulkan bahwa data regresi dalam penelitian ini tidak terjadi masalah autokorelasi.

\section{Uji Hipotesis}

Uji Koefisien Determinasi (Adjusted R')

Substruktur 1

Tabel 8.1 Hasil Uji Koefisien Determinasi 1

Model Summary

\begin{tabular}{lllll}
\hline Model & R & R Square & Adjusted R Square & Std. Error of the Estimate \\
\hline 1 & $.430(\mathrm{a})$ & .185 & .153 & 1.0127046 \\
\hline
\end{tabular}

Predictors: PENGENDALIAN INTERNAL, POLITIK DINASTI

Dependent Variable: AKUNTABILITAS

Sumber: Output SPSS 2017

Tabel 8.1 menunjukkan besarnya adjusted $R^{2}$ sebesar 0,153 , hal ini berarti $15,3 \%$ variabel Akuntabilitas dapat dijelaskan oleh 2 variabel independen Politik Dinasti dan Sistem Pengendalian Internal, sedangkan sisanya $(100 \%-15,3 \%=84,7 \%)$ dijelaskan oleh variabel lain diluar model penelitian.

\section{Substruktur 2}

Tabel 8.2 Hasil Uji Koefisien Determinasi 1

Model Summary ${ }^{\mathrm{b}}$

\begin{tabular}{lllll}
\hline Model & R & R Square & Adjusted R Square & Std. Error of the Estimate \\
\hline 1 & .420 (a) & .176 & .127 & .3478703 \\
\hline
\end{tabular}

Predictors: AKUNTABILITAS, PENGENDALIAN INTERNAL, POLITIK DINASTI

Dependent Variable: KINERJA

Sumber: Output SPSS 2017 
Tabel 8.2 menunjukkan besarnya adjusted $R^{2}$ sebesar 0,127 , hal ini berarti 12,7\% variabel Kinerja dapat dijelaskan oleh 3 variabel independen Politik Dinasti, Sistem Pengendalian Internal, dan Akuntabilitas sedangkan sisanya $(100 \%-12,7 \%=87,3 \%)$ dijelaskan oleh variabel lain diluar model penelitian.

\section{Analisis Regresi Linier Berganda}

\section{Substruktur 1}

Tabel 9.1 Hasil Uji Analisis Regresi Linier Berganda 1 Coefficients

\begin{tabular}{|c|c|c|c|c|c|c|}
\hline & & Coeff & & \multirow[b]{2}{*}{$\begin{array}{l}\text { Standardized } \\
\text { Coefficients }\end{array}$} & \multirow[b]{2}{*}{$\mathrm{t}$} & \multirow[b]{2}{*}{ Sig. } \\
\hline \multirow[t]{2}{*}{ Model } & & \multicolumn{2}{|c|}{$\begin{array}{l}\text { Unstandardized } \\
\text { Coefficients }\end{array}$} & & & \\
\hline & & $\mathrm{B}$ & Std. Error & Beta & & \\
\hline \multirow[t]{3}{*}{1} & (Constant) & 3.849 & .242 & & 15.894 & .000 \\
\hline & $\begin{array}{l}\text { POLITIK } \\
\text { DINASTI }\end{array}$ & -.715 & .279 & -.326 & -2.561 & .013 \\
\hline & $\begin{array}{l}\text { PENGENDALIAN } \\
\text { INTERNAL }\end{array}$ & 1.089 & .433 & .320 & 2.517 & .015 \\
\hline
\end{tabular}

Dependent Variable: AKUNTABILITAS

Sumber: Output SPSS, 2017

Berdasarkan tabel di atas, diperoleh persamaan regresi linier berganda sebagai berikut:

$\mathrm{Akt}=-0.326_{\mathrm{PD}}+0.320_{\mathrm{SPI}}+\varepsilon$

1) Koefisien regresi politik dinasti sebesar 0,326 dan bernilai negatif menyatakan bahwa setiap adanya pemerintahan daerah yang menjalankan praktik politik dinasti akan menurunkan tingkat akuntabilitas sebesar -0,326.

2) Koefisien regresi sistem pengendalian internal 0,320 dan bernilai positif menyatakan bahwa setiap bertambahnya penegakan SPI pada suatu pemerintahan daerah akan meningkatkan tingkat akuntabilitas sebesar 0,320.

Berdasarkan tabel di bawah, diperoleh persamaan regresi linier berganda sebagai berikut:

$\mathrm{Knj}=-0,066_{\mathrm{PD}}+0,366_{\mathrm{SPI}}+0,121_{\text {Akt }}+\varepsilon$

1) Koefisien regresi politik dinasti sebesar 0,066 dan bernilai negatif menyatakan bahwa setiap adanya pemerintah daerah yang menjalankan praktik politik dinasti dapat menyebabkan menurunnya tingkat capaian skor kinerja sebesar - 0,066.

2) Koefisien regresi sistem pengendalian internal sebesar 0,366 dan bernilai positif menyatakan

3) Koefisien regresi akuntabilitas sebesar 0,121 dan bernilai positif menyatakan bahwa setiap bertambahnya akuntabilitas laporan keuangan pemerintah daerah akan menaikkan capaian skor kinerja sebesar 0,121 .

\section{Substruktur 2}

Tabel 9.2 Hasil Uji Analisis Regresi Linier Berganda 2 Coefficients $^{a}$

\begin{tabular}{|c|c|c|c|c|c|c|}
\hline \multirow[t]{2}{*}{ Model } & & \multicolumn{2}{|c|}{$\begin{array}{l}\text { Unstandardized } \\
\text { Coefficients }\end{array}$} & \multirow{2}{*}{$\begin{array}{l}\text { Standardized } \\
\text { Coefficients } \\
\text { Beta }\end{array}$} & \multirow[t]{2}{*}{$\mathrm{t}$} & \multirow[t]{2}{*}{ Sig. } \\
\hline & & B & Std. Error & & & \\
\hline \multirow[t]{4}{*}{1} & (Constant) & 2.457 & .203 & & 12.104 & .000 \\
\hline & POLITIK DINASTI & -.049 & .102 & -.066 & -.480 & .633 \\
\hline & $\begin{array}{l}\text { PENGENDALIAN } \\
\text { INTERNAL }\end{array}$ & .420 & .158 & .366 & 2.668 & .010 \\
\hline & AKUNTABILITAS & .041 & .048 & .121 & .849 & .400 \\
\hline
\end{tabular}

Dependent Variable: KINERJA

Sumber: Output SPSS, 2017 


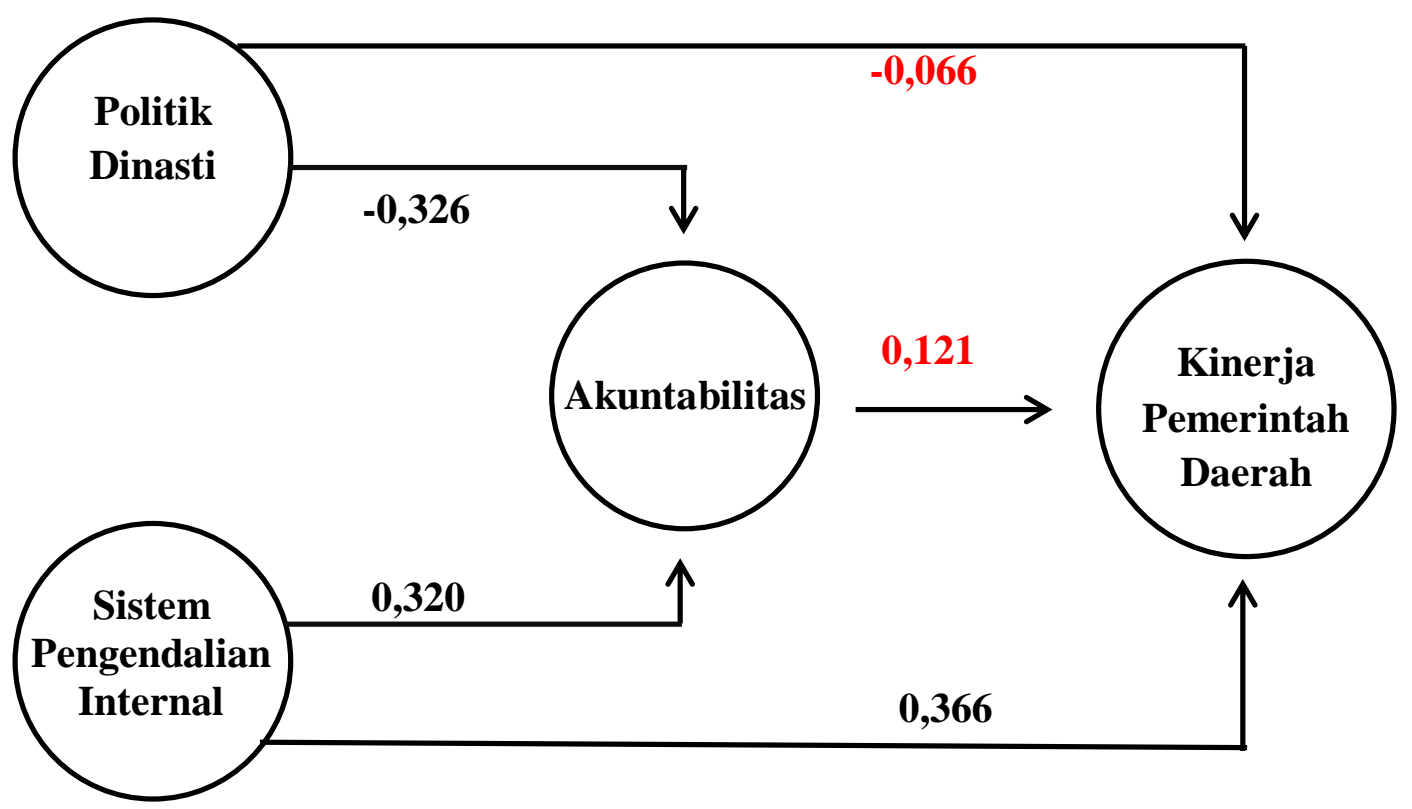

Gambar 2 Hasil Uji Path Analysis

Bahwa setiap bertambahnya penegakan SPI pada suatu pemerintahan daerah akan meningkatkan skor kinerja sebesar 0,366 .

\section{Uji Path Analysis}

Berdasarkan gambar 4 diatas:

1) Diketahui nilai signifikansi Politik Dinasti terhadap Akuntabilitas sebesar $0,013<0,05$ dan hasil dari $\left(\rho{ }^{*} \rho 4\right)$ atau $\left(-0,326^{*} 0,121\right)$, adalah $-0,039446$ sedangkan hasil dari $\rho 32$ yaitu $(-0,066) 2$ adalah 0,004356 sehingga $\left(\rho{ }^{*} \rho 4\right) \leq \rho 32$. Dapat disimpulkan bahwa Akuntabilitas bukan merupakan variabel intervening yang memediasi Politik Dinasti terhadap Kinerja.

2) Diketahui nilai signifikansi Sistem Pengendalian Internal terhadap Akuntabilitas sebesar 0,015 $<0,05$ dan hasil dari $\left(\rho 1^{*} \rho 4\right)$ atau $\left(0,320^{*} 0,121\right)$, adalah 0,03872 sedangkan hasil dari $\rho 32$ yaitu $(0,366) 2$ adalah 0,133956 sehingga $\left(\rho 2^{*} \rho 4\right) \leq \rho 52$. Dapat disimpulkan bahwa Akuntabilitas bukan merupakan variabel intervening yang memediasi Sistem Pengendalian Internal terhadap Kinerja.

\section{Politik Dinasti terhadap Akuntabilitas}

Berdasarkan pada tabel 4.13 hasil analisis Politik Dinasti dengan menggunakan regresi linear berganda menunjukkan Politik Dinasti dapat berpengaruh signifikan terhadap Akuntabilitas pelaporan keuangan daerah. Hal ini ditunjukkan dengan nilai koefisien regresi yang arahnya negatif sebesar $-0,715$, dengan signifikansi sebesar $0,013<$ alpha $(0,05)$ sehingga menunjukkan Politik Dinasti berkorelasi dan memiliki arah negatif terhadap Akuntabilitas. Maka, hipotesis kesatu $\left(\mathrm{H}_{1}\right)$ yang berbunyi Praktik Politik Dinasti Berpengaruh Negatif Terhadap Akuntabilitas Pelaporan Di Pemerintah Daerah dinyatakan diterima.

\section{Sistem Pengendalian Internal terhadap Akuntabilitas}

Berdasarkan pada tabel 4.13 hasil analisis Sistem Pengendalian Internal dengan menggunakan regresi linear berganda menunjukkan Sistem Pengendalian Internal tidak dapat berpengaruh 
signifikan terhadap Akuntabilitas pelaporan keuangan daerah. Hal ini ditunjukkan dengan nilai koefisien regresi yang arahnya positif sebesar 1,089, dengan signifikansi sebesar $0,015>$ alpha $(0,05)$ sehingga hasil tersebut menunjukkan Sistem Pengendalian Internal terbukti berpengaruh positif dan signifikan terhadap Akuntabilitas. Maka, hipotesis kedua $\left(\mathrm{H}_{2}\right)$ yang berbunyi Sistem Pengendalian Internal Berpengaruh Positif Terhadap Akuntabilitas Pelaporan Di Pemerintah Daerah dinyatakan diterima.

\section{Politik Dinasti terhadap Kinerja}

Berdasarkan pada tabel 4.14 hasil analisis Politik Dinasti dengan menggunakan regresi linear berganda menunjukkan Politik Dinasti tidak dapat berpengaruh signifikan terhadap Kinerja penyelenggaraan pemerintahan. Hal ini ditunjukkan dengan nilai koefisien regresi yang arahnya negatif sebesar -0,026, dengan signifikansi sebesar $0,803>$ alpha $(0,05)$ sehingga menunjukkan Politik Dinasti tidak berkorelasi. Maka, hipotesis ketiga $\left(\mathrm{H}_{3}\right)$ yang berbunyi Politik Dinasti Berpengaruh Negatif Terhadap Kinerja Pemerintah Daerah dinyatakan ditolak.

\section{Akuntabilitas terhadap Kinerja}

Berdasarkan pada tabel 4.14 hasil analisis Akuntabilitas dengan menggunakan regresi linear berganda menunjukkan variabel Akuntabilitas tidak dapat berpengaruh signifikan terhadap Kinerja penyelenggaraan pemerintahan. Hal ini ditunjukkan dengan nilai koefisien regresi yang arahnya positif sebesar 0,072 dengan signifikansi sebesar $0,128>$ alpha $(0,05)$ sehingga menunjukkan Akuntabilitas tidak berkorelasi, namun memiliki arah positif terhadap Kinerja. Maka, hipotesis keempat $\left(\mathrm{H}_{4}\right)$ yang berbunyi Akuntabilitas Berpengaruh Positif Terhadap Kinerja Pemerintah Daerah dinyatakan ditolak.

\section{Sistem Pengendalian Internal terhadap Kinerja}

Berdasarkan pada tabel 4.14 hasil analisis Sistem Pengendalian Internal dengan menggunakan regresi linear berganda menunjukkan Sistem Pengendalian Internal dapat berpengaruh signifikan terhadap Kinerja pemerintahan. Hal ini ditunjukkan dengan nilai koefisien regresi yang arahnya positif sebesar 0,679 , dengan signifikansi sebesar $0,034<$ alpha $(0,05)$ sehingga hasil tersebut menunjukkan Sistem Pengendalian Internal terbukti mempunyai arah positif dan berpengaruh secara signifikan terhadap Kinerja Pemerintah Daerah. Maka, hipotesis kelima $\left(\mathrm{H}_{5}\right)$ yang berbunyi Sistem Pengendalian Internal Berpengaruh Negatif Terhadap Kinerja Pemerintah Daerah dinyatakan diterima.

\section{Politik Dinasti terhadap Kinerja dengan akuntabilitas sebagai pemediasi}

Diketahui nilai signifikansi Politik Dinasti terhadap Akuntabilitas sebesar 0,013 $<0,05$ dan hasil dari $\left(\rho 1^{*} \rho 4\right)$ atau $\left(-0,326^{*} 0,121\right)$, adalah $-0,039446$ sedangkan hasil dari $\rho 32$ yaitu $(-0,066) 2$ adalah 0,004356 sehingga $\left(\rho 1^{*} \rho 4\right) \leq \rho 32$. Dapat disimpulkan bahwa Akuntabilitas bukan merupakan variabel intervening yang memediasi Politik Dinasti terhadap Kinerja. Maka, hipotesis keenanm $\left(\mathrm{H}_{6}\right)$ yang berbunyi Akunabilitas Pelaporan Memediasi Pengaruh Positif Politik Dinasti Terhadap Kinerja Pemerintah Daerah dinyatakan ditolak.

\section{Sistem Pengendalian Internal terhadap Kinerja dengan Akuntabilitas sebagai pemediasi}

Diketahui nilai signifikansi Sistem Pengendalian Internal terhadap Akuntabilitas sebesar 0,015 < 0,05 dan hasil dari $\left(\rho 1^{*} \rho 4\right)$ atau $\left(0,320^{*} 0,121\right)$, adalah 0,03872 sedangkan hasil dari $\rho 32$ yaitu $(0,366) 2$ adalah 0,133956 sehingga $\left(\rho 2^{*} \rho 4\right) \leq \rho 52$. Dapat disimpulkan bahwa Akuntabilitas bukan merupakan variabel intervening yang memediasi Sistem Pengendalian Internal terhadap Kinerja. 
Maka, hipotesis ketujuh $\left(\mathrm{H}_{7}\right)$ yang berbunyi Akunabilitas Pelaporan Memediasi Pengaruh Positif Sistem Pengendalian Internal Terhadap Kinerja Pemerintah Daerah dinyatakan ditolak.

\section{KETERBATASAN PENELITIAN}

Keterbatasan dalam penelitian ini adalah jumlah daerah yang diteliti pada penelitian ini sangat sedikit, hal ini dikarenakan penelitian ini menggunakan variabel SPI yang menggunakan temuan pelanggaran SPI sebagai proksinya namun hanya menemukan sedikit pelanggaran yang diungkap pada Laporan Hasil Pemeriksaan (LHP) BPK RI. Belum diterbitkannya laporan kinerja Pemerintah Daerah tahun 2016 oleh Kementrian Dalam Negeri mengurangi jumlah tahun pengujian pada penelitian ini. Rendahnya adjusted R2 dari model yang diuji dalam penelitian ini menunjukkan bahwa variabel lain yang tidak digunakan dalam penelitian ini mempunyai pengaruh yang lebih besar terhadap kinerja pemerintahan.

\section{KESIMPULAN}

Berdasarkan hasil penelitian dan pembahasan, maka dapat disimpulkan politik Dinasti berpengaruh terhadap Akuntabilitas pelaporan pada Pemerintah Daerah Kab/Kota tahun 20122015. Sistem Pengendalian Intern berpengaruh terhadap Akuntabilitas Pemerintah Daerah Kab/Kota tahun 2012-2015. Politik Dinasti tidak berpengaruh terhadap Kinerja pemerintahan pada Pemerintah Daerah Kab/Kota tahun 2012-2015. Akuntabilitas tidak berpengaruh terhadap Kinerja pemerintahan pada Pemerintah Daerah Kab/Kota tahun 2012-2015. Sistem Pengendalian Internal berpengaruh terhadap Kinerja pemerintahan pada Pemerintah Daerah Kab/Kota tahun 2012-2015. Akuntabilitas bukan merupakan variabel intervening yang memediasi Politik Dinasti terhadap Kinerja pemerintahan pada Pemerintah Daerah Kab/Kota tahun 2012-2015. Akuntabilitas bukan merupakan variabel intervening yang memediasi Sistem Pengendalian Internal terhadap Kinerja pemerintahan pada Pemerintah Daerah Kab/Kota tahun 2012-2015.

Saran dalam penelitian ini adalah penelitian selanjutnya diharapkan menggunakan periode pengamatan yang lebih lama untuk dapat memberikan kemungkinan yang lebih besar dalam mengetahui kondisi sebenarnya. Penelitian selanjutnya diharapkan dapat menambahkan atau menggunakan variabel lain yang mungkin dapat mempengaruhi Kinerja Pemerintahan Daerah. Penelitian selanjutnya diharapkan dapat mengembangkan jenis sampel secara lebih luas tidak hanya pada kepemimpinan daerah (eksekutif) saja, tetapi pada level legislatif dan hubungan istimewa lainnya didalam pemerintahan.

\section{DAFTAR PUSTAKA}

Adzani. A. H., \& Dwi, M. (2014). Pengaruh Kesejahteraan Masyarakat, Faktor Politik dan Ketidakpatuhan Regulasi Terhadap Opini Audit Laporan Keuangan Pemerintah Daerah, Simposium Nasional Akuntansi XVII: Mataram, Lombok.

Arens. A. A., Randal J. E., \& Beasley, M. S. (2008). Auditing and Assurance Services, Twelfth Edition, Terjemahan Herman Wibowo, Jakarta.

Arfan. D.A. (2014). Analisis Value for Money Dalam Pengukuran Kinerja Dinas Pertanian Daerah Istimewa Yogyakarta Periode Tahun 2011 - 2012, Skripsi. Universitas Negeri Yogyakarta, Indonesia.

Asako. Dkk (2010). Dynastic Legislators: Theory and Evidence from Japan, Working Papers, Waseda University Organization for Japan-US Studies.

Halim. A. (2014). Politik Lokal: Pola, Aktor \& Alur Dramatikalnya: Perspektif Teori Powercube, Modal dan Panggung, Lembaga Pengkajian Pembangunan Bangsa, Yogyakarta. 
Hidayatullah, A. (2015). Pengaruh Kejelasan Sasaran Anggaran, Pengendalian Akuntansi, Sistem Pelaporan Terhadap Akuntabilitas Kinerja SKPD Di Merauke, Unisbank, Semarang.

Irmawati, F. D. (2015). Pengaruh Kinerja Keuangan, Politik Dinasti, Dan Kinerja Pemerintah Daerah Terhadap Akuntabilitas Pelaporan Keuangan Pemerintah Daerah Di Indonesia Tahun 2012 - 2013, Jurnal Akuntansi dan Investasi. Universitas Muhammadiyah Yogyakarta, Yogyakarta.

Kautsar, I. (2015). Pengaruh Dinasti Politik Terhadap Akuntabilitas Keuangan Pemerintah Daerah Dan Kinerja Pemerintah Daerah di Indonesia, Universitas Gadjah Mada, Yogyakarta.

Kurrohman, T. (2013). Evaluasi Penganggaran Berbasis Kinerja Melalui Kinerja Keuangan Yang Berbasis Value for Money Di Kabupaten/Kota Di Jawa Timur, Jurnal Dinamika Akuntansi, UNNES, Semarang.

Nuritomo, R. H. (2014). Politik Dinasti, Akuntabilitas, Dan Kinerja Keuangan Pemerintah Daerah Di Indonesia, Simposium XVII Lombok, Lombok.

Pemerintah Republik Indonesia Peraturan Pemerintah Nomor 6 Tahun 2008 tentang Pedoman Evaluasi penyelenggaraan Pemerintah Daerah.

Pemerintah Republik Indonesia Peraturan Menteri Dalam negeri Nomor 73 tahun 2009 tentang Tata cara Pelaksanaan Evaluasi Kinerja Penyelenggaraan Pemerintah Daerah.

Pratolo, S. (2015). Audit Kinerja Manajemen, Konsep Dan Aplikasinya, LP3M, Yogyakarta.

Pratolo, S. (2016). Transparansi Dan Akuntabilitas Tata Kelola Pemerintahan Daerah dalam Hubungannya dengan Perwujudan Keadilan Dan Kinerja Pemerintah Daerah: Sudut Pandang Aparatur dan Masyarakat Di Era Otonomi Daerah. Jurnal Akuntansi dan Investasi, UMY, Yogyakarta.

Pratolo, S., Jatmiko, B., \& Anwar, M. (2016). Financial Statement Public Sectors Berbasis WebIct: Pola Pemetaan Laporan Keuangan Melalui Web-Ict Untuk Mewujudkan Transparansi Dan Akuntabilitas (Studi Kasus Skpd Kabupaten Bantul), Jurnal Akuntansi, Universitas Muhammadiyah Yogyakarta.

Sijabat, H. (2016). Pengaruh Opini, Temuan Audit, Kemandirian Dan Ukuran Pemerintah Daerah Terhadap Kinerja Penyelenggaraan Pemerintah Provinsi Di Indonesia Tahun 2010-2014, Universitas Lampung, Lampung.

Sudarsana, H.S. (2013). Pengaruh Karakteristik Pemerintah Daerah Dan Temuan Audit Bpk Terhadap Kinerja Pemerintah Daerah (Studi Pada Pemerintah Kabupaten/Kota di Indonesia), Skripsi. Universitas Diponegoro. 